\title{
Effect of fly ash on the corrosion performance and structural integrity of stainless steel concrete rebars in acid rain and saline environments
}

\author{
Angeliki G. Lekatou, Sofia Tsouli, Christos Nikolaidis, Spyridon Kleftakis \\ University of Ioannina, Department of Materials Science \&Engineering, Laboratory of Applied Metallurgy, 45110 Ioannina, Greece \\ alekaton@uoi.gr, bttps:/ / orcid.org/0000-0001-7951-4431 \\ sotsouli@cc.uoi.gr, bttps://orcid.org/0000-0002-5703-9403 \\ chrisnikolaid@hotmail.com, https://orcid.org/0000-0001-9336-6324 \\ skleftak@uoi.gr, https://orcid.org/0000-0001-6526-3758
}

Ilias K. Tragazikis, Theodoros E. Matikas

University of Ioannina, Department of Materials Science \&Engineering, Mechanics, Smart Sensors \& Nondestructive Evaluation

Laboratory, 45110 Ioannina, Greece

itragazik@cc.uoi.gr, bttps://orcid.org/0000-0001-9601-1908

matikas@otenet.gr, bttps://orcid.org/0000-0002-7912-5003

\begin{abstract}
The corrosion behavior of 304L stainless steel rebars in an alkaline solution simulating new concrete subjected to acid rain attack and a mildly to slightly acidic solution simulating corroded cover concrete that exposed the reinforcement to direct acid rain attack, was investigated by reverse polarization. Both solutions contained $\mathrm{Ca}(\mathrm{OH})_{2}$ and fly ash $(0-25$ wt. $\%$ of the dry mixture). Concrete cubes containing 0-25 wt.\% fly ash and reinforced with 304L rebars were subjected to salt spraying for $4 \mathrm{~m}$. Although the polarization behaviors in the two electrolytes were different, the relative trends with respect to the fly ash contents were similar. The beneficial effect of fly ash (up to $20 \mathrm{wt.} \%$ ) on the corrosion resistance of $304 \mathrm{~L}$ rebars was demonstrated. However, a deteriorating effect was realized at $25 \mathrm{wt} . \%$ addition. Partial replacement of cement by fly ash did not significantly affect the tensile properties of the 304L rebar before or after $4 \mathrm{~m}$ of salt spraying. The elastic modulus and percent elongation presented a slight decrease after $4 \mathrm{~m}$ of salt spraying, irrespectively of FA content. Corrosion-wise, 304L can replace 316L stainless steel provided that FA has been added to the concrete mixture, even at low contents (10 or $15 \mathrm{wt} . \%)$.
\end{abstract}

KEYWORDS. 304L rebars; Fly ash; Acid rain; Reverse polarization; Salt spraying; Tensile properties.

\section{OPEN $\bigcirc$ ACCESS}

Citation: Lekatou, A.G., Tsouli, S., Nikolaidis, C., Kleftakis, S., Tragazikis, I.K., Matikas T.E., Effect of fly ash on the corrosion performance and structural integrity of stainless steel concrete rebars in acid rain and saline environments, Frattura ed Integrità Strutturale, 50 (2019) 423-437.

Received: 21.01.2019

Accepted: 29.05.2019

Published: 01.10.2019

Copyright: (C) 2019 This is an open access article under the terms of the CC-BY 4.0, which permits unrestricted use, distribution, and reproduction in any medium, provided the original author and source are credited. 


\section{INTRODUCTION}

$\mathrm{T}$ he employment of modern materials in restoration works of ancient and modern monuments has been a common practice in the last decades. The application of AISI 316L stainless steel as a reinforcement of architectural members in the ancient theater of Dodona in the region of Epirus, Greece, is a typical example. With regard to the conservation of the monuments, the need for cost-effective combined with earthquake-resistant solutions is a critical factor to consider. Therefore, the replacement of an expensive steel reinforcement, like 316L steel, with a less expensive steel, like 304L, combined with low-cost corrosion inhibitors could become a more profitable alternative, as long as it proves an equally safe alternative. 304L austenitic stainless steel finds a wide variety of applications in many industrial fields as it combines a satisfactory corrosion performance, good mechanical properties and formability. Its good corrosion resistance is due to the $\mathrm{Cr}_{2} \mathrm{O}_{3}$-based passive film, the passivity of which is improved by the presence of nickel [1,2].

Reinforced concrete is the most widely used construction material due to its cost effectiveness, versatility and environmental compatibility, as well as its exceptional mechanical characteristics, longevity and corrosion resistance [3,4]. The great resistance to corrosion is owing to the chemical stability of the hydrated Portland cement and the passivity of steel in the highly alkaline pore solution of the concrete, its $\mathrm{pH}$ ranging from $\sim 12.5$ to $\sim 13.5$ [5-7].

Many historical buildings and monuments are located in urban and coastal regions and often in the vicinity of industrial areas. The consequent environmental-due deterioration of the reinforced concrete has been a serious problem in the last decades causing severe aesthetic, structural and economy issues. Corrosion of steel reinforcement is the most significant factor responsible for the premature deterioration of the serviceability, durability and seismic resistance of reinforced concrete structures. The two commonest types of atmospheric attack to the concrete, are: a) chloride infiltration into the concrete through its porous structure, when it is exposed to marine environments and deicing solutions and b) concrete carbonation, as a result of the reaction between the atmospheric $\mathrm{CO}_{2}$ (mostly in urban areas) and $\mathrm{Ca}(\mathrm{OH})_{2} \mathrm{Of}$ concrete [5]. Besides these two modes, concrete is also subjected to acid rain attack, as a consequence of the super-intensive urban and industrial activity during the last decades.

In the presence of $\mathrm{Cl}^{-}$, austenitic stainless steels embedded in carbonated or alkaline concrete, although still passive, can suffer localized (pitting or crevice) corrosion [8]. The interaction of $\mathrm{Cl}^{-}$with the concrete chemical constituents, results in the deposition of voluminous products in the concrete pores, subsequent stresses, cracking and $\mathrm{Cl}^{-}$access to the steel surface through the cracks [5]. Regarding the mechanical behavior of reinforcing steels due to chloride corrosion, a modest loss of strength but a marked reduction of the ductility of carbon steels have been shown $[9,10]$.

Carbonation-induced breakdown of passivity on stainless steel rebars is not an issue, since Cr-containing steels are expected to be passive in intermediate $\mathrm{pH}(\mathrm{pH} \sim 9)$ concrete pore solutions [11].

In the last decades, the degradation by acid rain has notably been accelerated, particularly in the aggressive environments of big cities, industrial areas, airports etc., causing serious damage in the durability and aesthetical value of architectures [12]. Acid rain (AR) attack and carbonation are interrelated since they both occur more frequently in urban areas with high concentrations of sulfur oxides $\left(\mathrm{SO}_{\mathrm{x}}\right)$ and nitrogen oxides $\left(\mathrm{NO}_{\mathrm{x}}\right)$, which in turn combine with the atmospheric water, to form sulfurous/sulfuric and nitrous/nitric acids [13]. Both, carbonation and AR attack of concrete lead to a decrease in basicity owing to acidic pollution. However, acid rain, a strongly corrosive medium, does not only contain $\mathrm{H}^{+}$, but also $\mathrm{NH}_{4}{ }^{+}, \mathrm{Mg}^{2+}, \mathrm{SO}_{4}{ }^{2-}, \mathrm{NO}_{3}, \mathrm{Cl}^{-}$, etc.; hence, the mechanism of concrete degradation by AR is more complex than the mechanism of pure acid attack [14]. Moreover, the various sources of AR (vehicle exhausts, internal combustion engines, power stations, smelters, pulp mills etc. that burn fossil fuels and natural sources like volcano eruptions, lightning strikes, pulp mills etc. [15]) cause a wide range of AR pH values and compositions in different regions of world.

The corrosion of steel reinforced concrete structures is accelerated by acid rain. More specifically, it is generally accepted that the acidic constituents of $\mathrm{AR}$ rapidly react with $\mathrm{Ca}(\mathrm{OH})_{2}$ to form hydrated salts soluble in rainwater. (It is recognized that Ordinary Portland Cement $(\mathrm{OPC})$ has minimal resistance to acid $(\mathrm{pH} \leq 3)$ attacks [16]). These solutions penetrate the interior of the concrete through its pores. After the evaporation of the rainwater, the salts redeposit causing stresses to the concrete pores. The resulting cracking and spalling of the concrete allows further inward diffusion of aggressive species and, eventually, corrosion and mechanical degradation of the steel reinforcement [14,17-19].

The significant influence of $\mathrm{H}^{+}$(dissolving erosion) and $\mathrm{SO}_{4}^{2-}$ (expanding erosion) contained in $\mathrm{AR}$ on the erosion, appearance and strength of cementitious materials has previously been manifested $[14,20]$. The degradation of the mechanical properties of the concrete (compressive strength, fracture toughness, modulus of elasticity, tensile properties) by AR has also been demonstrated [21-23].

Amongst the various methods applied to protect reinforced concrete against corrosion (corrosion inhibitors, epoxy coatings, steel galvanizing, industrial by-products and waste), the partial replacement of OPC with fly ash (FA) is a relatively inexpensive and ecological method [24,25], whilst causing a reduction of the unit cost of concrete [26]. The 
American Concrete Institute defines fly ash as "the finely divided residue that results from the combustion of ground or powdered coal and that is transported by flue gases from the combustion zone to the particle removal system" [27]. The beneficial effect of FA on the corrosion performance of reinforced and bare concrete has been reported in several investigations [25,26,28-30]. Through the pozzolanic reaction, fly ash transforms $\mathrm{Ca}(\mathrm{OH})_{2}$ from the cement hydration process into C-S-H (calcium silicate hydrate of variable stoichiometry $0.6-2.0 \mathrm{CaO} \cdot \mathrm{SiO}_{2} \cdot 0.9-2.5 \mathrm{H}_{2} \mathrm{O}$, often also incorporating partial substitution of $\mathrm{Al}$ for $\mathrm{Si}$ ), as follows [25]:

$$
\mathrm{Ca}(\mathrm{OH})_{2}+\mathrm{H}_{4} \mathrm{SiO}_{4} \rightarrow \mathrm{CaH}_{2} \mathrm{SiO}_{4} \cdot 2 \mathrm{H}_{2} \mathrm{O}
$$

Many pozzolans may also contain aluminate or $\mathrm{Al}(\mathrm{OH})_{4}^{-}$and silica that will react with $\mathrm{Ca}(\mathrm{OH})_{2}$ and $\mathrm{H}_{2} \mathrm{O}$ to form mixed calcium aluminate silicate hydrates of complex formulas. In the presence of $\mathrm{SO}_{4}{ }^{2-}, \mathrm{CO}_{3}{ }^{2-}, \mathrm{Cl}^{-}$, calcium monosulfoaluminate phases (often with substitution of $\mathrm{Fe}$ for $\mathrm{Al}$ and/or other anions, such as $\mathrm{OH}^{-}$or $\mathrm{CO}_{3}{ }^{2-}$ for $\mathrm{SO}_{4}{ }^{2-}$ ) and calcium trisulfoaluminate hydrate or ettringite $\left(\mathrm{Ca}_{6} \mathrm{Al}_{2}\left(\mathrm{SO}_{4}\right)_{3}(\mathrm{OH})_{12} \cdot 26 \mathrm{H}_{2} \mathrm{O}\right)$ sometimes with substitution of $\mathrm{Fe}$ for $\mathrm{Al}$ and/or $\mathrm{CO}_{3}{ }^{2-}$ for $\mathrm{SO}_{4}{ }^{2-}$ are formed [31]. The latter phases may lead to loss of mass and strength [26]. Papadakis has proposed a series of reactions describing the pozzolanic activity of a high-Ca fly ash with Portland cement [32].

C-S-H is more resistant than $\mathrm{Ca}(\mathrm{OH})_{2}$ to attacks of aggressive species, such as sulphates and chlorides [30]. The formation of C-S-H causes a decrease in the hydration heat release, drying shrinkage, porosity and permeability of concrete [24,25]. Other reaction products can also fill the capillary voids in the concrete, thus reducing its permeability. One such product is the Friedel's salt $\left(3 \mathrm{CaO} \cdot \mathrm{Al}_{2} \mathrm{O}_{3} \cdot \mathrm{CaCl}_{2} \cdot 10 \mathrm{H}_{2} \mathrm{O}\right)$ [25]. The filler effect of the fine particles of $\mathrm{FA}$ also contributes to the decrease in the porosity and permeability of the concrete [26]. The above attributes of FA have been shown to increase the compressive strength of concrete after long term exposure to $3.5 \% \mathrm{NaCl}$ [33]. However, not all types of FA benefit the corrosion resistance of concrete. Chousidis et al. noted that fly ash with significant amounts of clay minerals presents low resistance to chloride penetration and strength [25]. Additionally, Papadakis [32] concluded that the strength of Portland cement partially replaced by fly ash will exceed that of the cement only if the fly ash is richer in active silica as compared to the cement..

The existence of an optimum content of fly ash in concrete, as far as the corrosion performance of the steel reinforcement is concerned, was suggested in preliminary efforts [34,35]. This instigated a more integrated investigation of the effect of fly ash (FA) on the corrosion behavior of 304L rebars subjected to three different modes of accelerated testing: a) electrochemical degradation in a solution simulating concrete having suffered severe attack by acid rain; b) electrochemical degradation in a solution simulating concrete subjected to a mild attack by AR; c) mechanical degradation of rebars embedded in cubes of concrete by salt spraying for $4 \mathrm{~m}$. This work has been motivated by the limited information on the steel corrosion of reinforced concrete under acid rain and $\mathrm{H}_{2} \mathrm{SO}_{4}$-rich environments [28]. Corrosion studies and associated structural integrity studies on concrete combined with fly ash and reinforced with stainless steel rebars are even more rarely documented. The particular investigation is targeted to applications of ancient monument restorations in polluted urban environments and coastal environments.

\section{EXPERIMENTAL PROCEDURE}

ebars of austenitic stainless steels (304L of nominal wt. $\%$ composition: $0.03 \% \mathrm{C}, 18.00 \% \mathrm{Cr}, 8.00 \% \mathrm{Ni}, 1.00 \% \mathrm{Si}$, $2.00 \% \mathrm{Mn}, 0.0045 \% \mathrm{P}, 0.03 \% \mathrm{~S}$, Fe bal. and 316L of nominal wt. $\%$ composition: $0.022 \% \mathrm{C}, 17.31 \% \mathrm{Cr}, 10.08 \%$ $\mathrm{Ni}, 2.02 \% \mathrm{Mo}, 0.54 \% \mathrm{Si}, 1.75 \% \mathrm{Mn}, 0.0032 \% \mathrm{P}, 0.0001 \% \mathrm{~S}$, Fe bal.) having diameter of $6 \mathrm{~mm}$ and length of 2.5 $\mathrm{cm}$ were used for the electrochemical tests. $7 \times 7 \times 7 \mathrm{~cm}^{3}$ cubes of ordinary Portland cement (OPC) mixed with pulverized fly ash (FA) from the Hellenic Public Power Corporation lignite mines in the Region of Western Macedonia and reinforced with 304L rebars of $6 \mathrm{~mm}$ diameter and $12 \mathrm{~cm}$ length were employed for the salt spraying test. FA is of alkaline nature, with $\mathrm{CaO}$ being the main component, also containing $\mathrm{SiO}_{2}, \mathrm{Al}_{2} \mathrm{O}_{3}, \mathrm{SO}_{3}, \mathrm{Fe}_{2} \mathrm{O}_{3}$ and $\mathrm{MgO}$ [35]. These oxides form solid solutions, such as $\mathrm{CaCO}_{3}, \mathrm{CaSO}_{4}, 3 \mathrm{CaO} \cdot \mathrm{Al}_{2} \mathrm{O}_{3}, \mathrm{CaSiO}_{3}, 3 \mathrm{CaO} ! \mathrm{Al}_{2} \mathrm{O}_{3} ! \mathrm{Ca}(\mathrm{OH})_{2} \cdot 8 \mathrm{H}_{2} \mathrm{O}, \mathrm{Ca}(\mathrm{Mg}, \mathrm{Al})(\mathrm{Si}, \mathrm{Al})_{2} \mathrm{O}_{6}, \mathrm{AlFeO}_{3}$, $\mathrm{CaFe}^{2+} \mathrm{SiO}_{4}, \mathrm{CaAl}_{8} \mathrm{Fe}_{4} \mathrm{O}_{19}, \mathrm{CaFe}_{2}{ }^{3+}\left(\mathrm{SiO}_{4}\right)_{3}, \mathrm{Ca}_{3} \mathrm{SiO}_{5}, \mathrm{~K}_{0.9} \mathrm{Ca}_{5.8} \mathrm{Al}_{18.7} \mathrm{Si}_{14.15} \mathrm{O}_{32} . \mathrm{Al}_{2} \mathrm{O}_{3}, \mathrm{SiO}_{2}$ in the forms of quartz and cristobalite, as well as $\mathrm{CaO}$ and $\mathrm{Fe}_{2} \mathrm{O}_{3}$, have also been detected.

\section{Electrochemical testing}

304L rebar specimens of $2.5 \mathrm{~cm}$ length were subjected to potentiodynamic polarization testing. Their cut edges were mounted in epoxy resin and then encapsulated in PTFE leaving a surface of about $2 \mathrm{~cm}^{2}$ to be exposed to the electrolyte. A standard three electrode cell (with $\mathrm{Ag} / \mathrm{AgCl}$ as the reference electrode and a platinum gauze as the counter electrode) was 
connected to the Gill AC potensiostat/galvanostat by ACM Instruments. The corrosion current densities were determined by Tafel extrapolation, by conforming to several criteria analytically documented in previous efforts [36,37]. Reverse (or cyclic) polarization at a scan rate of $10 \mathrm{mV} / \mathrm{min}$ was carried out to evaluate the susceptibility of the rebars to localized corrosion. This technique is based on the concept of the hysteresis loop formed by the current density difference between the forward and reverse scans at the same potential. A negative hysteresis loop (i.e. a loop formed by anodic reverse scans corresponding to higher current densities than the current densities of the forward scans) signifies occurrence of localized corrosion [37].

Two types of electrolyte were used: a) The first electrolyte contained $(1.8-1.8 \mathrm{x} / 100) \mathrm{g}$ of agglomerates of $\mathrm{Ca}(\mathrm{OH})_{2}$ per 1 of an AR mimicking solution $(\mathrm{pH}=3.1)$. FA was added in the solution in amounts varying from $\mathrm{x}=0$ to 25 wt. $\%$ of $\left\{\mathrm{Ca}(\mathrm{OH})_{2}+\mathrm{FA}\right\}$. The $\mathrm{pH}$ of the electrolyte ranged from $4.5(0 \% \mathrm{FA})$ to $6.9(25 \% \mathrm{FA})$, postulated to represent concrete pores having become unsaturated due to acid attack. Considering that a $\mathrm{pH}$ acidity of 5.5-6.0 may be the limit of tolerance of high quality concrete in contact with various acids [19], this type of electrolyte can simulate the case of corroded cover concrete that exposed the reinforcement to direct AR attack possibly through cracks or pores. (316L bars were also tested in this electrolyte, for comparison reasons.) b) The second electrolyte consisted of an acid rain mimicking solution of $\mathrm{pH}=3.1$ containing $1.8 \mathrm{~g} / 1$ of a mixture of $\mathrm{Ca}(\mathrm{OH})_{2}$ powder and $\mathrm{FA}$, the latter in amounts varying from 0 to $25 \mathrm{wt} . \%$ of the dry mixture. The initial $\mathrm{pH}$ of the electrolyte was 11.7-11.8 irrespectively of the FA content. Considering that water saturated with $\mathrm{Ca}(\mathrm{OH})_{2}\left(1.8 \mathrm{~g} / 1\right.$ of $\left.\mathrm{H}_{2} \mathrm{O}\right)$ having a $\mathrm{pH}$ of $\sim 12.6$, simulates a concrete pore solution [38], a slightly acidified (due to AR) solution of $\mathrm{Ca}(\mathrm{OH})_{2}$ (mixed with varying amounts of $\mathrm{FA}$ ) is postulated to represent new concrete having been subjected to an AR attack that is expected to have a mild effect on the steel reinforcement. In the case of the alkaline electrolyte, only anodic polarization was carried out. In the case of the acidic electrolyte, cathodic polarization preceded anodic polarization, in order to attain even more aggressive conditions due to reduction reactions of surface oxides.

Here it is noted that the interaction of the above electrolytes with the steel cannot simulate the kinetics of AR attack to reinforced concrete. Nevertheless, the results presented in the following sections intend to clarify whether the effect of FA on the rebar corrosion has a consistent trend regardless of the severity of attack and also to provide an understanding of this trend. The acid rain mimicking solution had the following composition in $\mathrm{g} / \mathrm{l}$ of $\mathrm{H}_{2} \mathrm{O}: \mathrm{H}_{2} \mathrm{SO}_{4}: 0.032, \mathrm{HNO}_{3}: 0.015,\left(\mathrm{NH}_{4}\right)_{2} \mathrm{SO}_{4}$ : 0.046, $\mathrm{Na}_{2} \mathrm{SO}_{4}: 0.032, \mathrm{NaNO}_{3}: 0.021$ and $\mathrm{NaCl}: 0.084$ [39].

The microstructure of the polarized 304L specimens (cross-sectioned at ribs by a diamond saw and polished by standard metallographic procedure) was inspected by Scanning Electron Microscopy (SEM)/Energy Dispersion X-ray spectroscopy (EDX) at the JeoL JSM 6510 LV system equipped with an Oxford Instruments X- Act EDX analyzer.

\section{Salt spraying and tensile property evaluation}

Concrete cubes reinforced with 304L rebars underwent salt spray testing for $4 \mathrm{~m}$ in a Vötch chamber $\left(5 \mathrm{wt} . \% \mathrm{NaCl}, 35{ }^{\circ} \mathrm{C}\right)$. The stainless steel/concrete/salt fog junction was coated by epoxy glue.

Uniaxial tensile testing of the rebars was performed before and after $2 \mathrm{~m}$ and $4 \mathrm{~m}$ of salt spraying in a Galdabini $100 \mathrm{kN}$ Universal Testing Machine (ASTM E8/E8M-09, ambient temperature, cross-head speed: $1.30 \mathrm{~mm} / \mathrm{min}$ ).

The modulus of elasticity of the embedded, before and after salt spraying, was determined by ultrasound testing (Pulseecho technique). In the pulse-echo mode, the sound is reflected back to the device; hence, the transducer performs both the sending and the receiving of the pulsed waves. This technique determines the elastic modulus through measurements of the velocity of propagation of the longitudinal ultrasonic waves and the velocity of propagation of the shear ultrasonic waves in the specimen. These measurements are based on the principle that ultrasonic waves are stress waves propagating in materials when introducing small elastic deformations (in the order of $10^{-7} \mathrm{~mm}$ ) of the material. Hence, the dynamic moduli of a material can be determined by using the wave propagation equations according to the linear elasticity theory. These equations are analytically described in [40]. The experimental setup for the velocity measurements included piezoelectric transducers ( $\mathrm{x}$-cut: longitudinal wave generation and $\mathrm{y}$-cut: shear wave generation). The ultrasonic acquisition and analysis were performed by the UTWin software. Honey was used as a couplant between the transducer and the specimen. The ultrasonic frequencies of the longitudinal and shear waves were $10 \mathrm{MHz}$.

\section{RESULTS AND DISCUSSION}

\section{Cyclic polarization in the low $\mathrm{pH}$ electrolyte}

7 he cyclic polarization behavior of $304 \mathrm{~L}$ rebars during immersion in an electrolyte containing $\mathrm{Ca}(\mathrm{OH}) 2$, acid rain simulating solution and fly ash at different contents at mildly to slightly acidic $\mathrm{pHs}(4.5,5.4,6.1,6.5,6.9$ at $0,10,15$, 20, 25 wt. \% FA, respectively) and alkaline pHs (11.8, 11.7, 11.7, 11.8, 11.7 at 0, 10, 15, 20, 25 wt.\% FA, respectively) is shown in Figs.1 (a,b), respectively. 
The majority of the anodic polarization curves in Fig.1 a form negative hysteresis loops (i.e. higher current densities at reverse scanning in comparison with the forward scanning for the same potential); hence, it is suggested that 304L has suffered from localized corrosion. Yet, all voltammograms except those corresponding to 0 and $25 \mathrm{wt} \%$ FA, present anodic-to-cathodic transition potential $\left(\mathrm{E}_{\mathrm{a} / \mathrm{ctr}}\right)$ values that are higher than or almost equal to the corrosion potential ( $\left.\mathrm{E}_{\text {corr }}\right)$ values; this indicates nobler or equally noble surfaces at $\mathrm{E}_{\mathrm{a} / \mathrm{c}}$ tr than or to those at $\mathrm{E}_{\text {corr }}$ (forward polarization). Fig.1a reveals comparably large surface areas of the negative hysteresis loops at 0 and $25 \mathrm{wt} . \% \mathrm{FA}$, evidence of marked localized corrosion. All forward anodic portions except that of $0 \mathrm{wt} . \% \mathrm{FA}$ include regimes of significant current density decrease; furthermore, the current limiting current densities are lower than $0.1 \mathrm{~mA} / \mathrm{cm}^{2}$, implying surface films of low conductivity.

Fig. 1a shows that the corrosion potential $\left(\mathrm{E}_{\mathrm{corr}}\right)$ increases as the FA content increases, indicating nobler steel surfaces with FA. This increase has previously been explained by the $\mathrm{pH}$ increase with FA [34]. The $\mathrm{pH}$ increase with FA could be the outcome of hydration reactions of the Ca-silicate components of $\mathrm{FA}$ that readily yield $\mathrm{OH}$ - ions when reacting with water [41]:

$$
3 \mathrm{CaO} \cdot \mathrm{SiO}_{2}+3.90 \mathrm{H}_{2} \mathrm{O} \rightarrow 1.68 \mathrm{CaO} \cdot \mathrm{SiO}_{2} \cdot 2.58 \mathrm{H}_{2} \mathrm{O}+1.32 \mathrm{Ca}(\mathrm{OH})_{2}
$$

(Here it should be noted, that the $\mathrm{Ca}(\mathrm{OH})_{2}$ amount of the solution produced by hydration should be counterbalanced by the $\mathrm{Ca}(\mathrm{OH})_{2}$ consumption from other phases in the FA [32]. However, in the low pH electrolyte, the Ca ${ }^{2+}$ content of the electrolyte is not enough to provide the necessary $\mathrm{Ca}(\mathrm{OH})_{2}$ to react with the phases of $\mathrm{FA}$ ).

Fig. 1a also reveals that addition of FA (up to $20 \mathrm{wt} . \%$ ) has resulted in a shift of the forward polarization curves to lower current densities. Moreover, the anodic curves corresponding to 10-20 wt.\% FA present a good resistance to localized corrosion as suggested by the small surface areas of the negative hysteresis loops or even the positive hysteresis loops. This decrease in the corrosion kinetics is expected considering the decrease in the $\mathrm{H}^{+}$concentration of the electrolyte with FA increasing. However, the trend of corrosion resistance increasing with FA content is reversed at 25 wt. $\%$ FA. Not only is the hysteresis negative but the hysteresis loop presents a surface area markedly larger than those of the 10-20 wt.\% FA anodic voltammograms. In addition, the current densities of the " $25 \mathrm{wt} . \%$ FA" anodic voltammogram appear notably higher than those of the $20 \mathrm{wt} . \%$ anodic voltammogram, implying accelerated corrosion kinetics.

\section{Cyclic polarization in the bigh $p H$ electrolyte}

Fig. $1 \mathrm{~b}$ reveals a different corrosion status than that in the low $\mathrm{pH}$ electrolyte. All anodic curves reveal passive regimes of high potential range and very low current density values, much lower than $0.1 \mathrm{~mA} / \mathrm{cm}^{2}$, evidence of true passivity. Reverse polarization has led to positive hysteresis for the " $0-20 \mathrm{wt} . \%$ FA" voltammograms, and a slightly negative hysteresis for the " 25 wt.\% FA" voltammogram. The positive hysteresis is more extensive (in terms of loop surface area) in the cases of 15 and 20 wt. \% FA. All curves present $E_{a} / \mathrm{c}$ tr values nobler than the respective $E_{\text {cor }}$ values (or equally noble in the case of 25 wt.\% FA). Therefore, it is concluded that localized corrosion has not taken place. Regarding the case of 25 wt. $\%$ FA, the very low current values during the passive regime, imply that localized corrosion is not an issue either.

Nevertheless, the relative trends of the voltammograms with respect to the FA contents are very similar to those observed in the low $\mathrm{pH}$ electrolyte, namely: increase in the corrosion resistance with FA increasing up to 20 wt.\% FA and deterioration at 25 wt. $\%$ FA. The latter is implied by the shift of the current densities to lower values, the slightly negative hysteresis and the insignificantly lower $\mathrm{E}_{\mathrm{a} / \mathrm{c} \text { tr }}$ value as compare to the respective $\mathrm{E}_{\mathrm{cor}}$ value.

Fig.1b shows that the corrosion potential increases as the FA content increases, as in Fig.1a. The increase in Ecor with FA (up to $20 \mathrm{wt} . \%$ FA) can be justified by the respective increase in the pozzolanic activity. Nobler half-cell potentials of steel rebars embedded in $3.5 \mathrm{wt} . \% \mathrm{NaCl}$ have been attributed to higher pozzolanic activity [25].

In the "25 wt.\% FA" case, 304L exhibits "worst" passive behavior than that corresponding to the " 20 wt. \% FA" case, in compatibility with the trends in the low $\mathrm{pH}$ electrolyte. However, conversely to the steel in the low $\mathrm{pH}$ environment, the steel has not suffered from localized corrosion. The most plausible explanation for the relatively high conductivity of the passive film in the case of $25 \mathrm{wt} . \% \mathrm{FA}$ is the extensive deposition of highly hydrated films on 304L, as described in Introduction. Moreover, the particular FA, due to its high $\mathrm{Ca}$ and fineness, has a high ability for water binding [25,32].

At this point, it is considered appropriate to make a comment on the insensitivity of $\mathrm{pH}$ to the FA addition: It seems that the aforementioned counterbalance between the $\mathrm{Ca}(\mathrm{OH})_{2}$ amount generated from reaction $(2)$ and the $\mathrm{Ca}(\mathrm{OH})_{2}$ consumed from other phases in the FA [32] exists in the high $\mathrm{pH}$ electrolyte, resulting in $\mathrm{pH}$ values that do not change with the increase in the FA content. Also, retainment of the $\mathrm{pH}$ of the solution at 11.7-11.8 regardless of the FA content suggests that the pozzolanic reaction occurrence was maintained during the polarization tests. This suggestion is based on the following consideration: For the initiation and maintenance of the pozzolanic reaction, a sufficient quantity of $\mathrm{Ca}^{2+}$ and a high $\mathrm{pH}(>12)$ are necessary, since at the $\mathrm{pH}$ of $\sim 12$, the $\mathrm{Si}^{4+}$ and $\mathrm{Al}^{3+}$ ions have sufficient solubility to support the pozzolanic reaction [42]. 

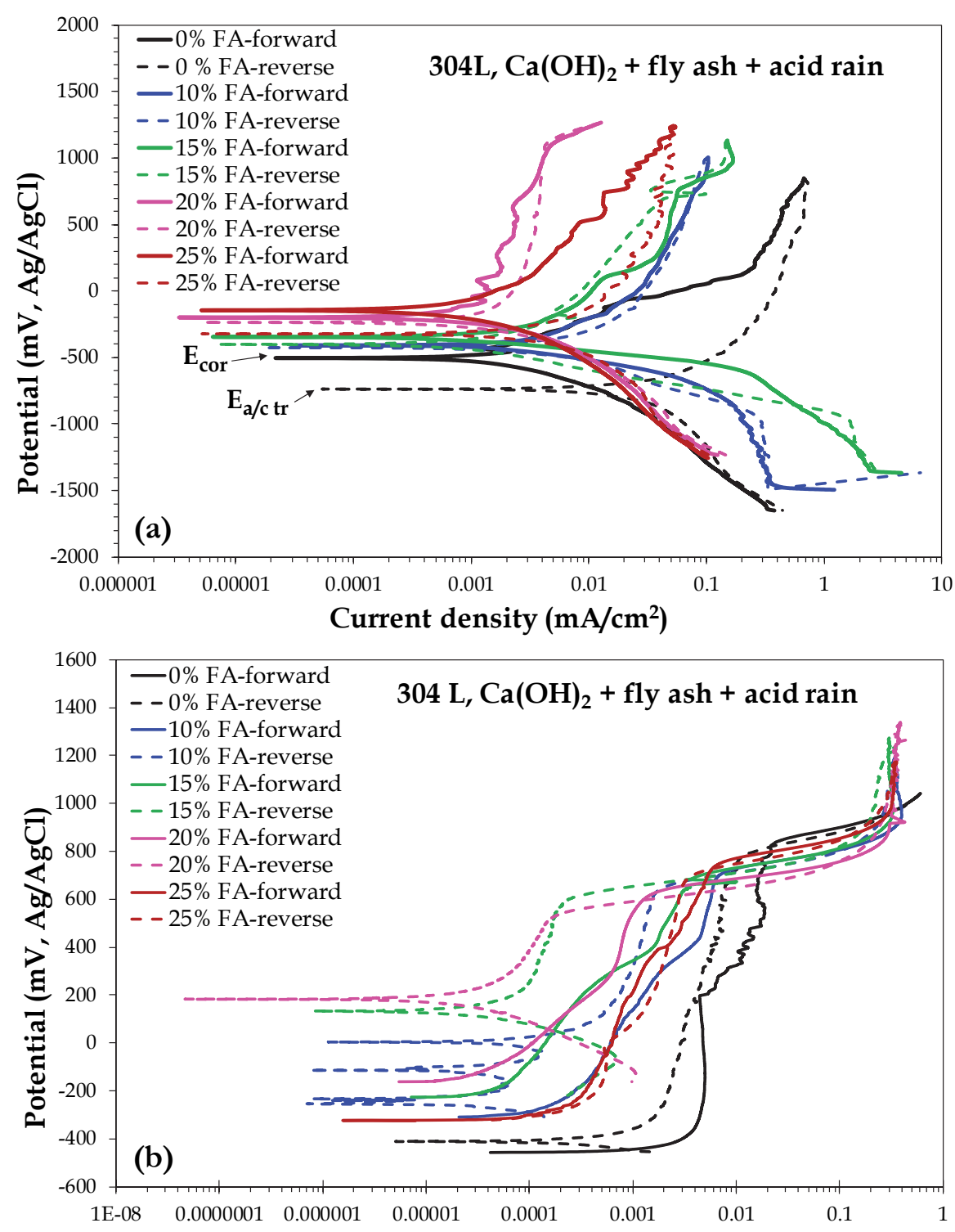

Current density $\left(\mathrm{mA} / \mathrm{cm}^{2}\right)$

Figure 1: Cyclic polarization curves of 304L rebars in electrolytes containing $\mathrm{Ca}(\mathrm{OH})_{2}$, acid rain simulating solution and fly ash at different contents: (a) acidic pHs, anodic and cathodic scans; (b) alkaline pHs, anodic scans.

Fig. 2 compares the voltammograms of 304L rebars immersed in the two electrolytes. The superiority of the corrosion performance of 304L in the high $\mathrm{pH}$ electrolyte is clear, both kinetically-wise (curves shifted to lower currents as compared to the acidic solutions) and thermodynamically-wise (nobler corrosion potentials as compared to the acidic solutions). Higher pHs, favour stability of the passive films (According to the respective Pourbaix diagrams [43], in the corrosion potential range of this work, both $\mathrm{Cr}$ and $\mathrm{Ni}$ can be active at $\mathrm{pHs}<4-5$ ). The nobler corrosion potential values in the case of the alkaline $\mathrm{pHs}$ as compared to those in the case of the mildly acidic pHs can be justified by the smaller difference between the reversible potentials for metal $(\mathrm{Fe}, \mathrm{Cr}, \mathrm{Ni})$ dissolution and oxygen reduction in alkaline solutions in comparison with the difference between the reversible potentials for oxygen reduction in aerated mildly acidic solutions.

\section{Comparison of 304L and 316L electrochemical performances}

Fig.3 compares the forward voltammograms of $316 \mathrm{~L}$ and 304L rebars polarized in the same electrolyte. The higher corrosion resistance of $316 \mathrm{~L}$ rebars as compared to $304 \mathrm{~L}$ rebars, with regard to slower corrosion kinetics (shift of polarization curves to lower currents) and less thermodynamic tendency for corrosion (nobler $\mathrm{E}_{\text {corr }}$ ) is manifested. Previous work has demonstrated the high resistance of the 316L rebars to localized corrosion [35]. The inferior corrosion performance of the 


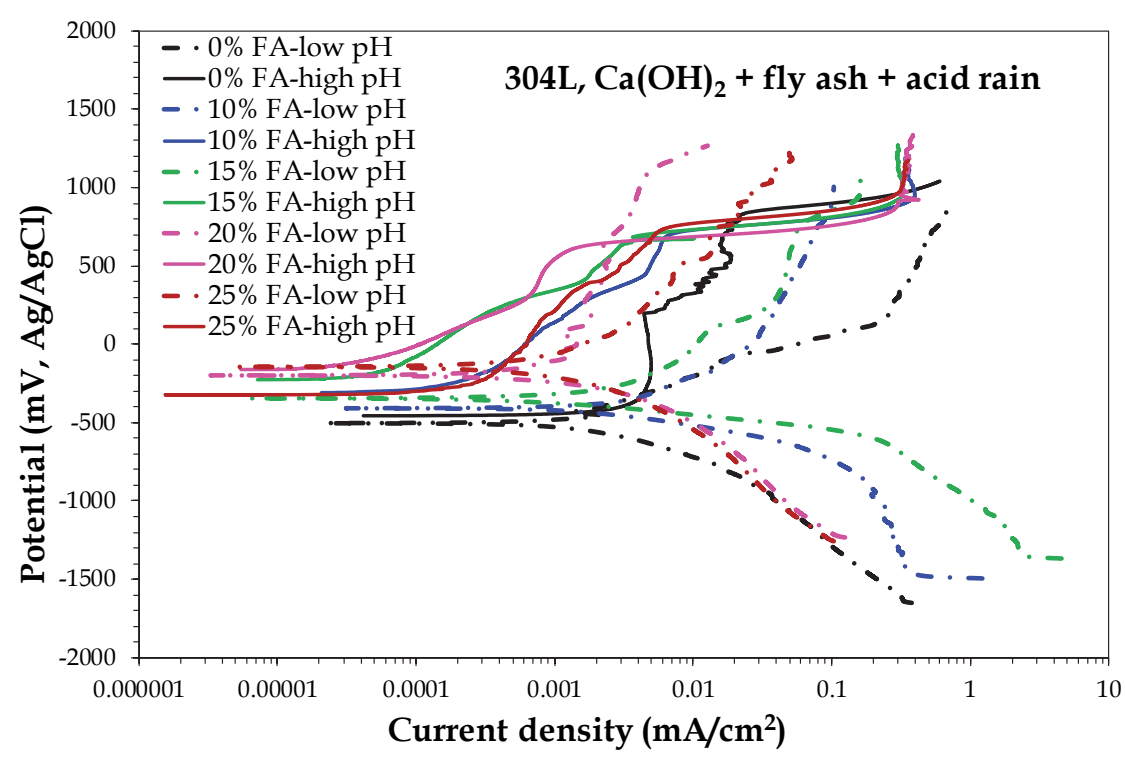

Figure 2: Comparison of the polarization behaviors (forward scans) of 304L rebars in two electrolytes (an acidic one and an alkaline one) containing $\mathrm{Ca}(\mathrm{OH})_{2}$, acid rain simulating solution and fly ash at different contents.

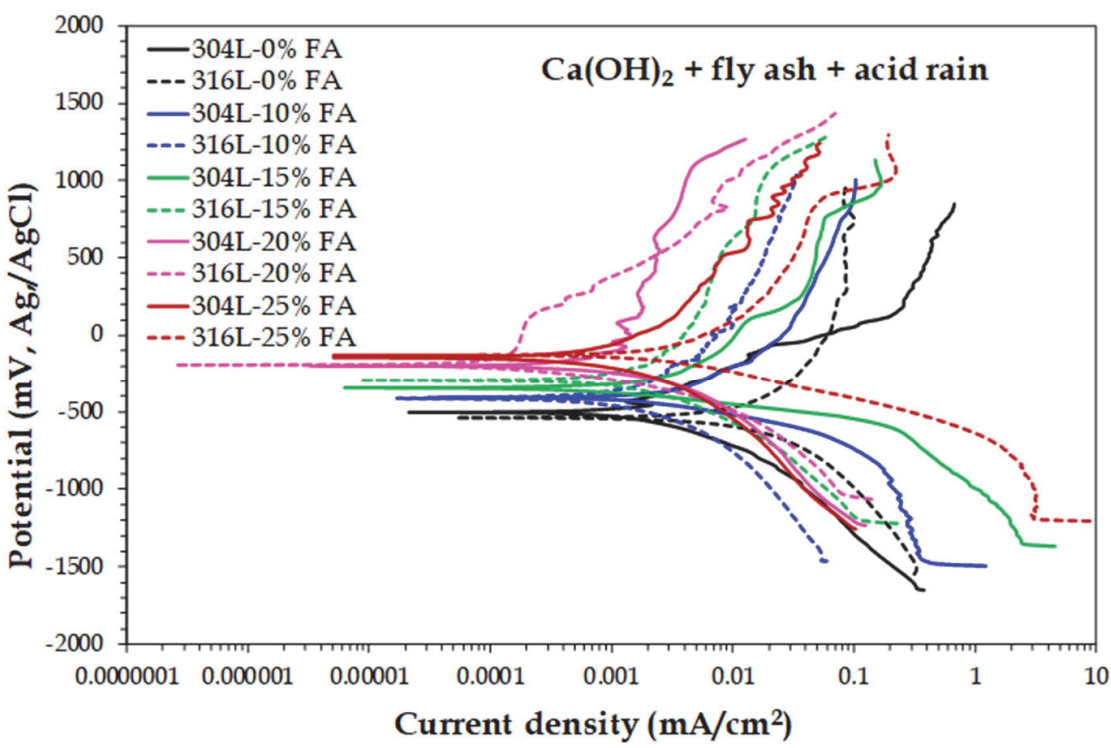

Figure 3: Comparison of the polarization behaviors (forward scans) of $316 \mathrm{~L}$ and $304 \mathrm{~L}$ rebars in an electrolyte containing $\mathrm{Ca}(\mathrm{OH})_{2}$, acid rain simulating solution and fly ash at different contents.

304L rebars as compared to the 316L rebars is mainly attributed to the absence of Mo and the higher content of S. Mo increases the pitting corrosion resistance in chloride containing solutions, whilst sulfur (as sulfides) promotes stress corrosion cracking and pitting [44]. The relative electrochemical trends of both steels, as far as the FA content of the solution is concerned, are similar: Increasing FA contents lead to slower corrosion kinetics. This trend is reversed at 25 wt. $\%$ FA. The most interesting observation though, is that even 10 wt. $\%$ or 15 wt. $\%$ replacement of $\mathrm{Ca}(\mathrm{OH})_{2}$ with FA has led to notably slower corrosion kinetics of $304 \mathrm{~L}$ as compared to $316 \mathrm{~L}$ in $\mathrm{Ca}(\mathrm{OH})_{2}$ solution free of FA. Hence, the potential of using the relatively inexpensive 304L (as compared to 316L) in the restoration of ancient monuments, provided that fly ash is employed as a corrosion inhibitor, is herein indicated.

\section{Microstructure of corroded rebars}

This section attempts to elucidate the deterioration of the electrochemical behavior of the $304 \mathrm{~L}$ rebars at the $25 \mathrm{wt} . \% \mathrm{FA}$ (case of acidic electrolyte). To start with, Fig.4 illustrates micrographs of rebars after cyclic polarization in the acidic electrolyte, at relatively low magnifications. A fine surface state has been maintained, in all cases of FA contents. 
Higher magnifications in Fig.5 manifest the positive effect of FA addition on the corrosion resistance of the 304L rebars in the low pH electrolyte. Fig.5 shows more or less compact films uniformly deposited on the surface of 304L, in the cases of the 20 wt. \% FA (Figs.5(a-d)) and 25 wt.\% FA (Figs.5(e-g)). These films are probably products of interaction between $\mathrm{Ca}(\mathrm{OH})_{2}$-FA. The interaction is drawn from the detection of (besides $\mathrm{Ca}$ ) Si, Al, S and occasionally $\mathrm{Mg}$ on them. The detection of noticeable amounts of $\mathrm{Ca}, \mathrm{Si}, \mathrm{Al}, \mathrm{S}, \mathrm{Mg}, \mathrm{O}$ and $\mathrm{Cl}$ in the EDX spectrum of Fig.5b constitutes evidence that pozzolanic type reactions have occurred between $\mathrm{Ca}(\mathrm{OH})_{2}, \mathrm{H}_{2} \mathrm{O}$, FA and probably AR, leading to the formation of complex compositions, as reported in Introduction. Also, the detection of $\mathrm{Cl}^{-}$raises the possibility of salt formation analogous to the Friedel's salt. The detection of $\mathrm{Cr}$ and $\mathrm{Fe}$ (Fig.5b) indicates interaction between $\mathrm{FA}, \mathrm{Ca}(\mathrm{OH})_{2}$ and steel.
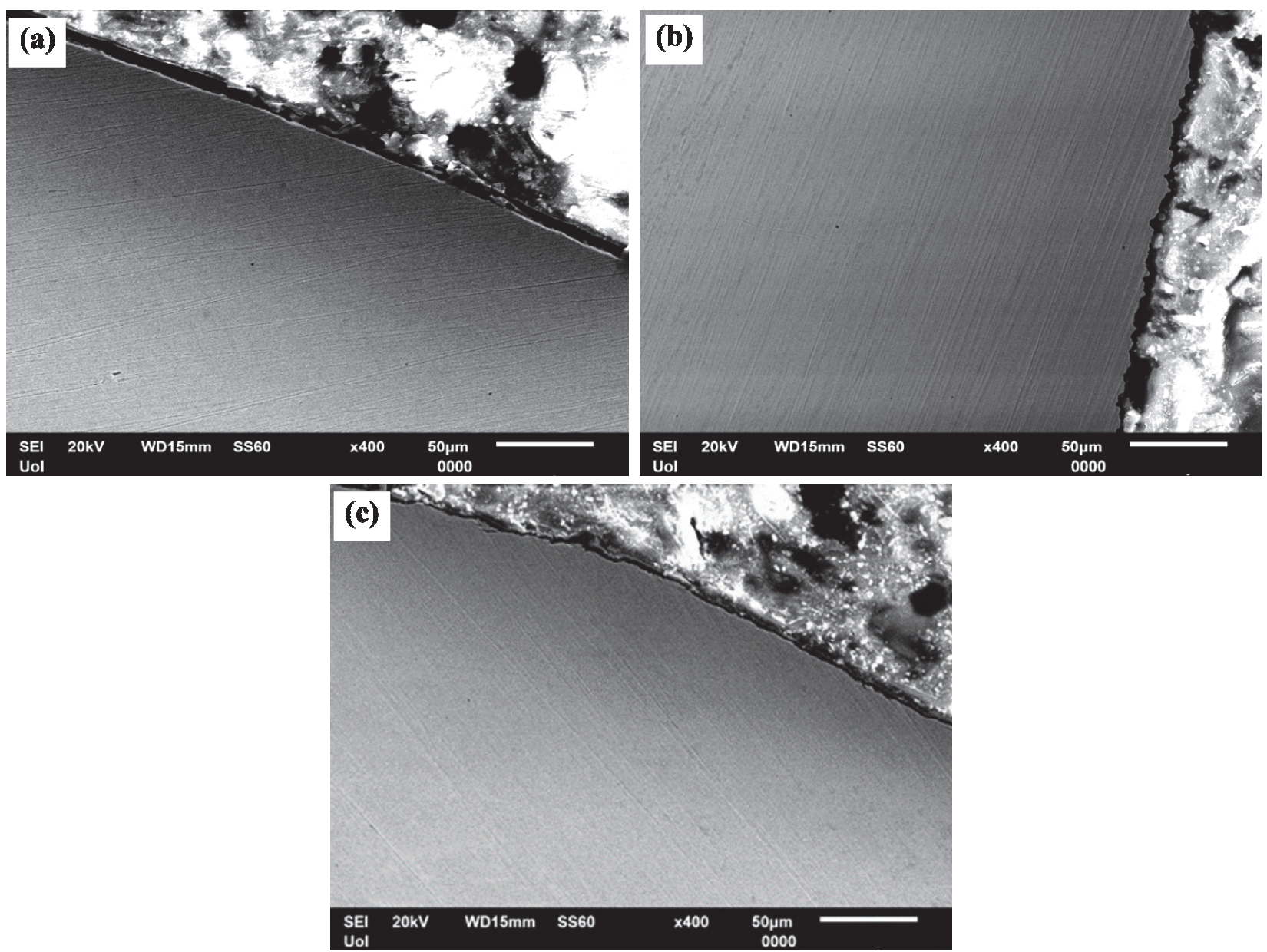

Figure 4: Cross-sections of 304L rebars after cyclic potentiodynamic polarization in acidic electrolyte containing $\mathrm{Ca}(\mathrm{OH})_{2}$, acid rain simulating solution and (a) $0 \mathrm{wt} . \%$ fly ash, (b) $20 \mathrm{wt} . \%$ fly ash and (c) $25 \mathrm{wt} . \%$ fly ash (wt. \%: with respect to $\left(\mathrm{Ca}(\mathrm{OH})_{2}+\right.$ fly ash)).

However, Fig.6 demonstrates that FA may also have a destructive effect on the corrosion resistance of the 304L rebars at high FA amounts. Acicular pits appear to be associated with high FA additions, in the following manner: Agglomerates of FA do not have a vigorous pozzolanic activity with $\mathrm{Ca}(\mathrm{OH})_{2}$ due to their low specific surface area as compared to the fine particles. As such, they will not form a uniformly deposited C-S-H film on the surface of the steel, which is resistant to aggressive ion penetration. Instead, the agglomerates can locally form thick deposits on the steel surface. Consequently, differential aeration cells may be formed, where the steel below a relatively compact part of the deposit (reduced $\left.\mathrm{pO}_{2}\right)$ acts as an anode and the steel below a less dense part of the deposit (higher $\mathrm{pO}_{2}$ ) acts as a cathode. The anode corrodes forming pits filled with corrosion products (from FA-Ca(OH) 2 -AR-steel interactions).

A complementary reason for the localized corrosion observed at high FA amounts in the low pH electrolyte, can be the extensive formation of hydrated sulphates by the interaction of $\mathrm{FA}-\mathrm{Ca}(\mathrm{OH})_{2}-\mathrm{AR}$, as mentioned in Introduction. When this formation takes place in a preexisting defect of the steel surface, the resulting volume expansion will exert stresses to the defect and eventually stress corrosion cracking. This reason can justify the formation of acicular pits with short but needle-like branches, as well as for the detection of high concentrations of sulfur inside the pits (as shown in Fig.6b). 

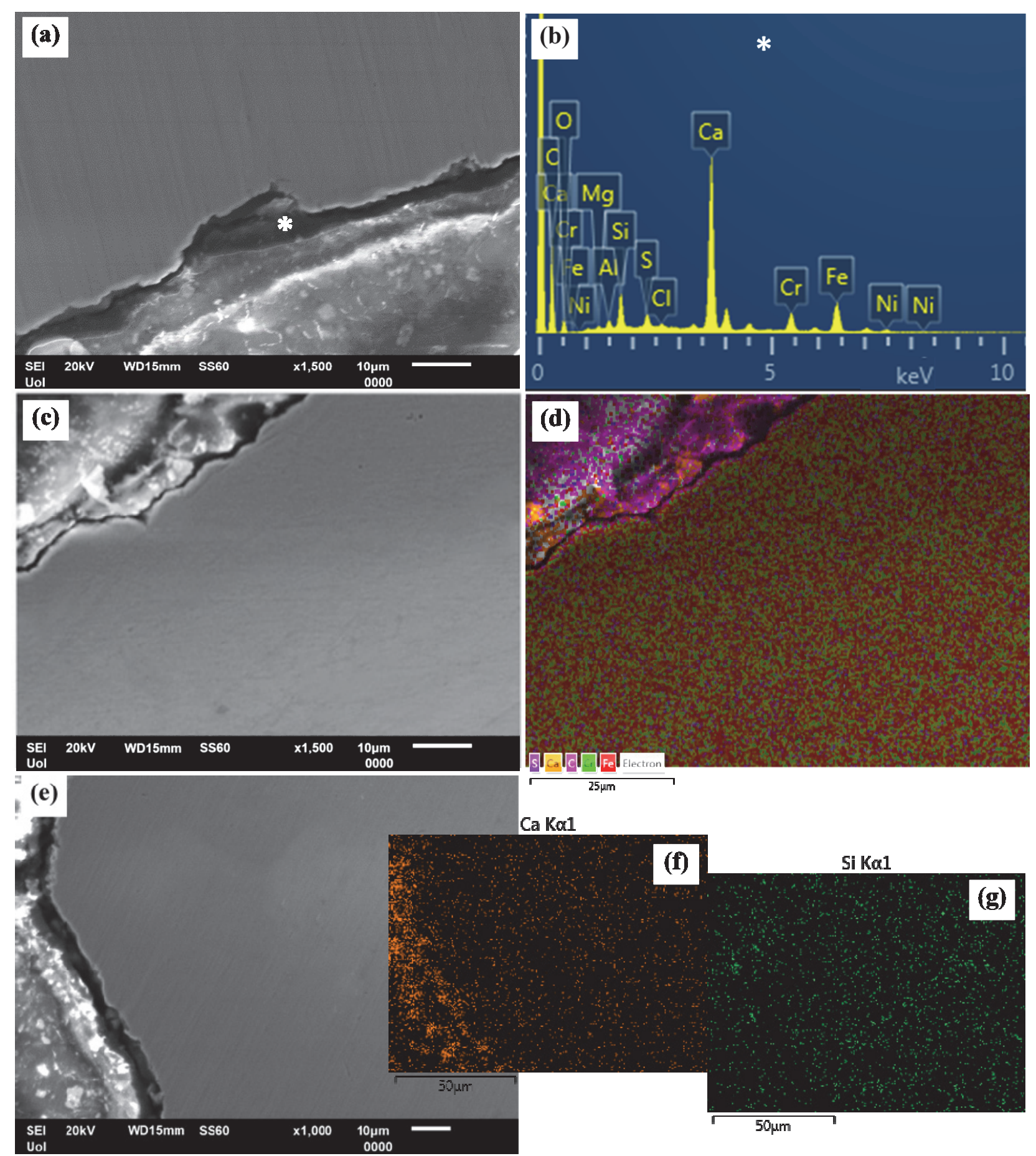

Figure 5: SEM cross-sectional micrographs of 304L rebar after cyclic polarization in acidic electrolyte containing $\mathrm{Ca}(\mathrm{OH})_{2}$, acid rain simulating solution and (a)-(d) $20 \mathrm{wt} . \%$ fly ash, (e) $25 \mathrm{wt} . \%$ fly ash (wt.\%: with respect to $\left(\mathrm{Ca}(\mathrm{OH})_{2}+\right.$ fly ash) ), showing the deposition of films on the steel surface; (b) representative EDX point analysis from the steel surface film in (a); (d): EDX elemental mapping of (c); (f) \& (g): EDX mapping for $\mathrm{Ca}$ and $\mathrm{Si}$, respectively.

Some comments on the role of fly ash

Although the acid rain simulating environment in this effort does not quite correspond to the actual rain kinetics through reinforced concrete, the findings have given a sound evidence of the effect of fly ash on the electrochemical behavior of the reinforcement under the attack of $\mathrm{AR}$ to the rebar. Two different cases have been investigated: (a) in the first case, $\mathrm{Ca}(\mathrm{OH})_{2}$ could not act as an acid buffer due to its low volume in the acid rain mimicking solution. In this case, fly ash acted as the 

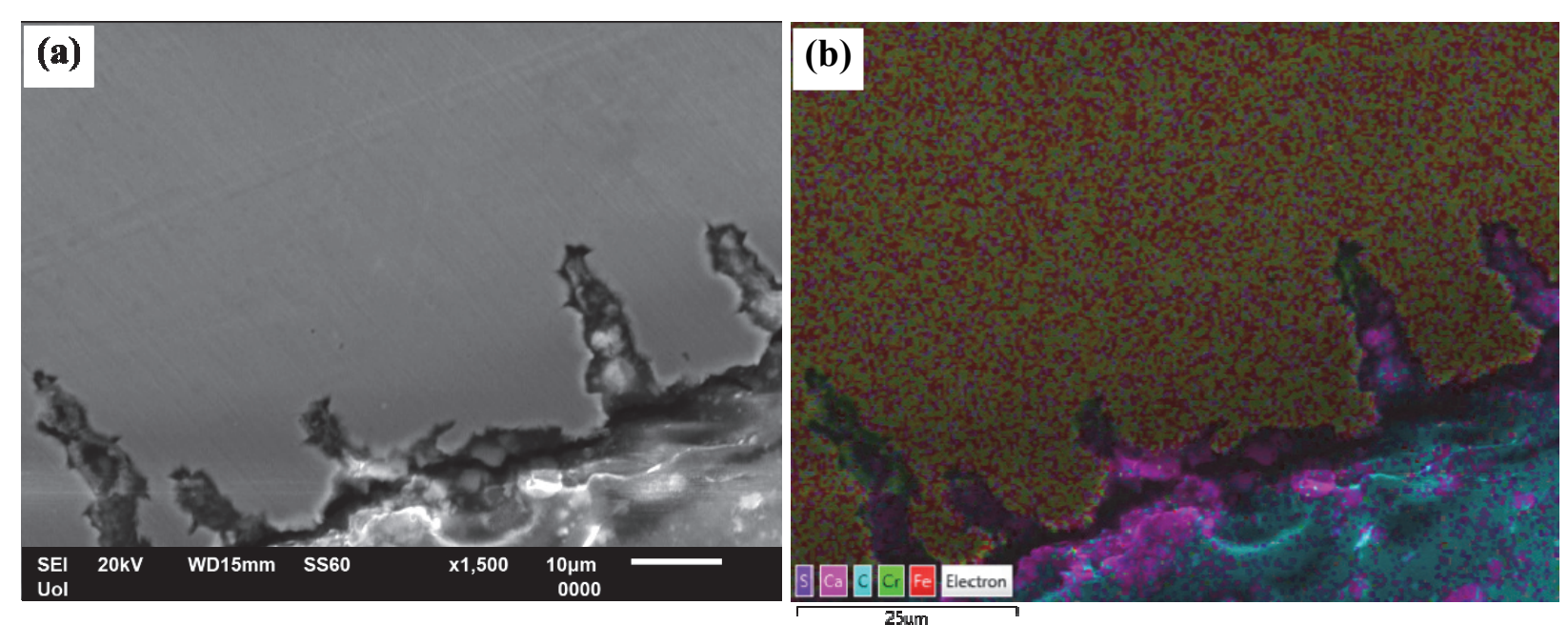

Figure 6: (a) Cross-sectional micrograph of 304L rebar after cyclic polarization in acidic electrolyte containing $\mathrm{Ca}(\mathrm{OH})_{2}$, acid rain simulating solution and $25 \mathrm{wt} . \%$ fly ash (with respect to dry $\mathrm{Ca}(\mathrm{OH})_{2}$ ), showing pitting and (b) respective EDX elemental mapping.

main acid buffering medium causing an increase in the alkalinity of the electrolyte with fly ash content increasing; (b) in the second case, the high volume of $\mathrm{Ca}(\mathrm{OH})_{2}$ in the acid rain mimicking solution acted as a strong acid buffer, regardless of the alkaline fly ash concentration; therefore, it can be claimed that a main effect of $\mathrm{Ca}(\mathrm{OH})_{2}$ partial replacement by FA was the decrease in the $\mathrm{Ca}(\mathrm{OH})_{2}$ content available for reaction with acid [45]. (Acidic gases, such as $\mathrm{SO}_{2}, \mathrm{HNO}_{3}$ and $\mathrm{HCl}_{\text {readily }}$ react with $\mathrm{Ca}(\mathrm{OH})_{2}$ to form $\mathrm{CaSO}_{4} \cdot 2 \mathrm{H}_{2} \mathrm{O}, \mathrm{Ca}(\mathrm{NO} 3)_{2} \cdot 4 \mathrm{H}_{2} \mathrm{O}, \mathrm{CaCl}_{2} \cdot 6 \mathrm{H}_{2} \mathrm{O}$, etc. [17]. These compounds are dissolved in the rainwater, facilitating the ingress of $\mathrm{Cl}^{-}$to the steel surface). More analytically, this work suggests that the beneficial effect of FA on the corrosion performance of $304 \mathrm{~L}$ rebars stems from the following reasons:

a) Deposition of products of chemical interactions between the involved species (C-S-H, calcium sulfoaluminates, calcium aluminate silicate hydrates) that are more resistant than $\mathrm{Ca}(\mathrm{OH})_{2}$ to aggressive ions [16,33]. Furthermore, the detection of chlorine in the surface film of Figs.5(a,b) indicates the formation of salts analogous to the Friedel's salt that may trap $\mathrm{Cl}^{-}$ by chemical and/or physical bonding, hence delaying and/or limiting the aggressive $\mathrm{Cl}$ access into the interior of the steel. b) Partial replacement of $\mathrm{Ca}(\mathrm{OH})_{2}$ by supplementary cementitious materials, which decrease the $\mathrm{Ca}(\mathrm{OH})_{2}$ content available for reaction with the AR constituents, in compatibility with [16,17].

c) In the case of the low $\mathrm{pH}$ environment, the positive effect of FA is also attributed to the increase in the pH with $\mathrm{FA}$ content increasing, as already mentioned.

\section{Salt spray and tensile tests}

Figs.7(a-d) illustrates 304L reinforced concrete cubes containing 20 wt.\% FA (a \& b) and 25 wt.\% FA(c \& d) after salt spraying for $4 \mathrm{~m}$. Visual examination reveals a good surface state for the specimens.

Fig. 8 presents the stress-strain curves of the reinforcing bars as a function of the FA content for the periods of $0 \mathrm{~m}$ and $2 \mathrm{~m}$ of salt spraying. Table 1 shows the tensile property values extracted from the stress-strain curves.

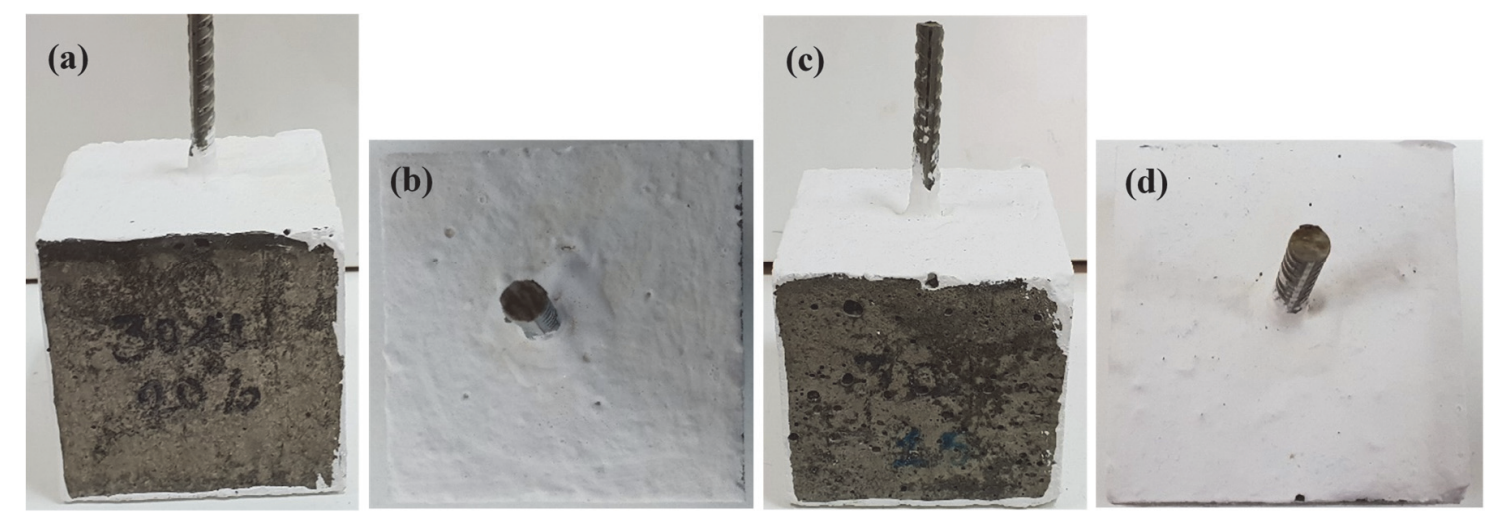

Figure 7: 304L reinforced concrete cubes after $4 \mathrm{~m}$ in the salt spray chamber: (a) \& (b): $20 \mathrm{wt} . \%$ fly ash containing, side-view and top view, respectively; (c) \& (d) 25 wt.\% fly ash containing, side-view and top view, respectively. 
Fig.8 shows that the FA addition does not significantly affect the tensile properties of the 304L reinforcement before or after salt spraying. However, a trend of a slight decrease in the elastic modulus with FA increasing may be observed. Despite within statistical error, this decreasing trend is consistent for all the FA percentages and the 3 periods of salt spray test. Although it cannot be claimed that the latter constitutes evidence of increased steel corrosion with FA increasing, it has to be mentioned that there are works, which have shown that the concentration of total chlorides in cements exposed to saline environments increases with increasing FA content at $12 \mathrm{~m}$ of immersion due to salt crystallization into the pores of concrete; as a result, a reinforcing steel mass loss increasing with FA content in the cement is observed [33,46]. Nevertheless, longer exposure $(18 \mathrm{~m})$ results in similar concentrations of chloride content due to a decrease in the percentage of chloride binding capacity as compared to the total chloride content [33]. Thomas reported that under marine environments, the positive effects of fly ash become more significant with time, as the fly ash containing concrete shows marked reductions of chloride penetrability with time [47].

Fig.9 demonstrates the tensile behavior of the reinforcing bars as a function of the salt spraying duration. Regarding the yield strength and the tensile strength, a slightly decreasing trend seems to be realized after $4 \mathrm{~m}$ of salt spraying. This decreasing trend is consistent for all FA percentages, except $15 \mathrm{wt} \%$ FA. However, regarding $\sigma_{\mathrm{y}}$, it falls within statistical error in all other FA percentages; regarding $\sigma_{t}$, it falls within statistical error in 20 and $25 \mathrm{wt} . \%$ FA. The decreasing trend is clearer and
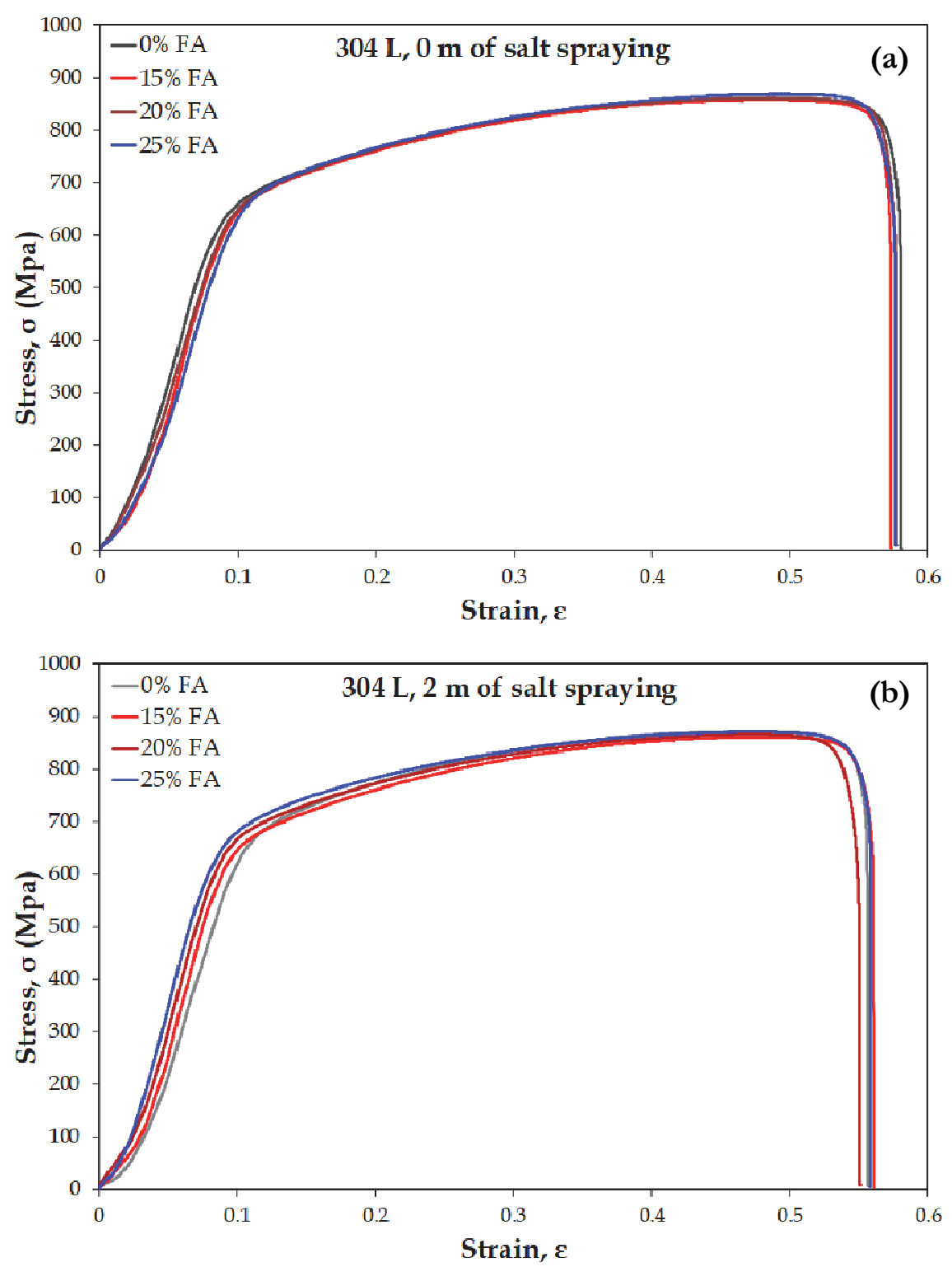

Figure 8: Stress-strain curves of 304L rebars embedded in concrete with different fly ash (FA) contents: (a) before salt spraying, and (b) after $2 \mathrm{~m}$ of salt spraying. 


\begin{tabular}{|c|c|c|c|c|c|c|}
\hline $\begin{array}{l}\text { Duration } \\
\text { (m) }\end{array}$ & $\begin{array}{l}\text { Fly ash } \\
\text { (wt.\%) }\end{array}$ & $\begin{array}{c}\mathrm{E} \\
(\mathrm{GPa})\end{array}$ & $\begin{array}{c}\sigma_{\mathrm{y}} 0.2 \% \\
(\mathrm{MPa})\end{array}$ & $\begin{array}{c}\sigma_{\mathrm{t}} \\
(\mathrm{MPa})\end{array}$ & $\begin{array}{c}\sigma_{\mathrm{f}} \\
(\mathrm{MPa})\end{array}$ & $\% \mathrm{EL}$ \\
\hline \multirow[t]{4}{*}{0} & 0 & $200 \pm 1$ & $597 \pm 15$ & $780 \pm 28$ & $751 \pm 40$ & $44 \pm 1$ \\
\hline & 15 & $200 \pm 1$ & $610 \pm 27$ & $782 \pm 23$ & $751 \pm 27$ & $42 \pm 0$ \\
\hline & 20 & $199 \pm 0$ & $586 \pm 15$ & $754 \pm 16$ & $707 \pm 9$ & $43 \pm 1$ \\
\hline & 25 & $199 \pm 0$ & $592 \pm 8$ & $753 \pm 11$ & $707 \pm 16$ & $42 \pm 1$ \\
\hline \multirow[t]{4}{*}{2} & 0 & $200 \pm 0$ & $592 \pm 14$ & $763 \pm 22$ & $731 \pm 22$ & $41 \pm 1$ \\
\hline & 15 & $196 \pm 0$ & $552 \pm 40$ & $726 \pm 49$ & $690 \pm 45$ & $40 \pm 1$ \\
\hline & 20 & $194 \pm 1$ & $577 \pm 22$ & $749 \pm 21$ & $704 \pm 27$ & $40 \pm 2$ \\
\hline & 25 & $190 \pm 0$ & $595 \pm 24$ & $767 \pm 28$ & $717 \pm 34$ & $41 \pm 1$ \\
\hline \multirow[t]{4}{*}{4} & 0 & $190 \pm 1$ & $573 \pm 11$ & $739 \pm 14$ & $718 \pm 11$ & $37 \pm 1$ \\
\hline & 15 & $189 \pm 2$ & $599 \pm 12$ & $783 \pm 13$ & $750 \pm 13$ & $41 \pm 2$ \\
\hline & 20 & $189 \pm 3$ & $571 \pm 56$ & $738 \pm 81$ & $680 \pm 47$ & $40 \pm 4$ \\
\hline & 25 & $188 \pm 1$ & $572 \pm 20$ & $732 \pm 19$ & $709 \pm 22$ & $38 \pm 0$ \\
\hline
\end{tabular}

Table 1: Effect of fly ash content (of the dry concrete mixture) and salt spraying duration on the tensile properties of 304L rebars embedded in concrete. E: modulus of elasticity, $\sigma_{\mathrm{y}} 0.2 \%$ : yield strength, $\sigma_{\mathrm{t}}$ : tensile strength, $\sigma_{\mathrm{f}}$ : fracture strength \%EL: percent elongation.

more consistent, in the cases of the modulus of elasticity and the percent elongation. The decrease in the elongation with time of corrosion is compatible with previous works $[9,10]$, which showed that the influence of corrosion on the yield point and tensile strength of concrete steel reinforcement is markedly less than that on the elongation. This is because fracture starts from the point of pitting leading to brittle fracture [10].

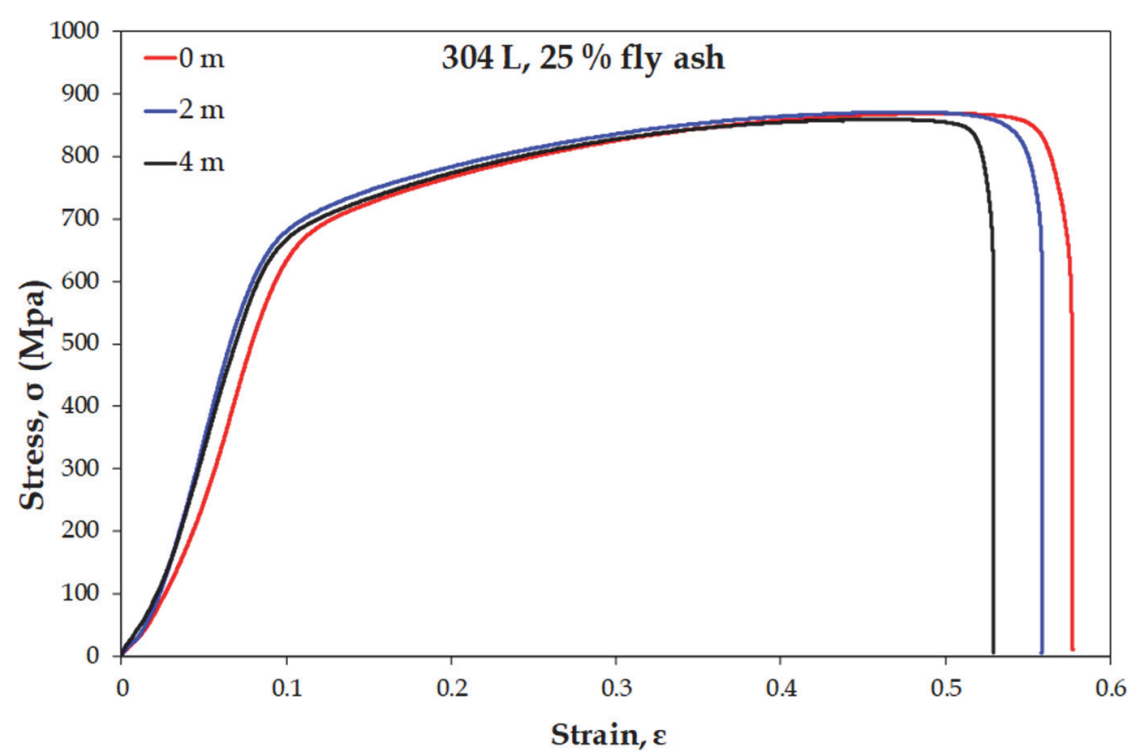

Figure 9: Effect of salt spraying time on the stress-strain behavior of 304L rebars embedded in concrete containing 25 wt. $\%$ fly ash.

\section{CONCLUSIONS}

yclic potentiodynamic polarization of 304L stainless steel rebars in an acid rain simulating solution containing $\mathrm{Ca}(\mathrm{OH})_{2}$ and different fly ash (FA) quantities at slightly acidic pHs has shown drastically limiting current regimes but some susceptibility to localized corrosion (10-20 wt.\% FA). An increase in the FA addition (up to $20 \mathrm{wt} . \%$ ) has resulted in an increase in the corrosion resistance. However, this trend was reversed at $25 \mathrm{wt} . \% \mathrm{FA}$. 
Cyclic potentiodynamic polarization of $304 \mathrm{~L}$ stainless steel rebars in an acid rain simulating solution containing $\mathrm{Ca}(\mathrm{OH})_{2}$ and different fly ash (FA) quantities at alkaline $\mathrm{pHs}$, reveals true passivity and non-occurrence of localized corrosion. The relative trends of the voltammograms corresponding to the different FA contents are very similar to those observed in the low $\mathrm{pH}$ electrolyte. Similarly to the case of the low pH electrolyte, the trend of corrosion resistance increasing with FA addition was reversed at $25 \mathrm{wt} \%$ FA.

A clear superiority of the corrosion performance of 304L in the high $\mathrm{pH}$ electrolyte over that in the low $\mathrm{pH}$ electrolyte has been exhibited.

The feasibility of replacing 316L stainless steels in critical applications, such as the restoration of ancient monuments, provided that FA is included in the concrete mixture as a corrosion inhibitor, even at low contents (10 or 15 wt. $\%)$, has been manifested.

Microstructural examination of $304 \mathrm{~L}$ corroded in the acidic electrolyte revealed that a main reason for the positive effect of the FA addition is the formation of films -products of $\mathrm{Ca}(\mathrm{OH})_{2}$-fly ash-acid rain chemical interaction. However, high FA amounts (in this case $25 \mathrm{wt} . \% \mathrm{FA}$ ), promote localised corrosion.

Not any visual indications of corrosion have been observed in concrete cubes reinforced with $304 \mathrm{~L}$ rebar during salt spraying for $4 \mathrm{~m}$. Partial replacement of cement by fly ash did not significantly affect the tensile properties of the 304L rebar before or after salt spraying except a slight decrease in the elastic modulus with FA increasing within statistical error though. Longer exposures are needed for safer conclusions on the effect of fly ash. The modulus of elasticity and the percent elongation presented a slight decrease after $4 \mathrm{~m}$ of salt spraying, irrespectively of the FA contents.

\section{REFERENCES}

[1] Olsson, C.-O.A. and Landolt, D. (2003). Passive films on stainless steels-chemistry, structure and growth, Electrochim. Acta, 48(9), pp. 1093-1104. DOI: 10.1016/S0013-4686(02)00841-1.

[2] Addari, D., Elsener, B. and Rossi, A. (2008). Electrochemistry and surface chemistry of stainless steels in alkaline media simulating concrete pore solutions, Electrochim. Acta, 53(27), pp. 8078-8086. DOI: 10.1016/j.electacta.2008.06.007.

[3] Mahdikhani, M., Bamshad, O. and Fallah Shirvani, M. (2018). Mechanical properties and durability of concrete specimens containing nano silica in sulfuric acid rain condition, Constr. Build. Mater., 167, pp. 929-935.

DOI: $10.1016 /$ j. conbuildmat.2018.01.137.

[4] Monticelli, C., Natali, M.E., Balbo, A., Chiavari, C., Zanotto, F., Manzi, S. and Bignozzi, M.C. (2016). Corrosion behavior of steel in alkali-activated fly ash mortars in the light of their microstructural, mechanical and chemical characterization, Cem. Concr. Res., 80, pp. 60-68. DOI: 10.1016/j.cemconres.2015.11.001.

[5] Hansson, C.M., Poursaee, A. and Jaffer, S.J. (2012). Corrosion of reinforcing bars in concrete, The Masterbuilder, pp. 106-124. Available at: http://www.masterbuilder.com.

[6] Mundra, S., Criado, M., Bernal, S.A. and Provis, J.L. (2017). Chloride-induced corrosion of steel rebars in simulated pore solutions of alkali-activated concretes, Cem. Concr. Res., 100, pp. 385-397. DOI: 10.1016/j.cemconres.2017.08. 006.

[7] Sharifi-Asl, S., Mao, F., Lu, P., Kursten, B. and Macdonald, D.D. (2015). Exploration of the effect of chloride ion concentration and temperature on pitting corrosion of carbon steel in saturated $\mathrm{Ca}(\mathrm{OH})_{2}$ solution, Corros. Sci., 98, pp. 708-715. DOI: 10.1016/j.corsci.2015.06.010.

[8] Bertolini, L., Bolzoni, F., Pastore, T. and Pedeferri, P. (1996). Behaviour of stainless steel in simulated concrete pore solution, Brit. Corros. J., 31(3), pp. 218-222. DOI: $10.1179 / 000705996798114572$.

[9] Apostolopoulos, Ch.A., Demis, S. and Papadakis, V.G. (2013). Chloride-induced corrosion of steel reinforcement Mechanical performance and pit depth analysis, Constr. Build. Mater., 38, pp. 139-146.

DOI: 10.1016/j.conbuildmat. 2012.07.087.

[10] Lee, H. and Cho, Y. (2009). Evaluation of the mechanical properties of steel reinforcement embedded in concrete specimen as a function of the degree of reinforcement corrosion, Int. J. Fracture, 157(1-2), pp. 81-88. DOI: $10.1007 /$ s10704-009-9334-7.

[11] Hurley, M.F. and Scully, J.R. (2006). Threshold chloride concentrations of selected corrosion-resistant rebar materials compared to carbon steel, Corrosion, 62(10), pp. 892-904. DOI: 10.5006/1.3279899.

[12] Camuffo, D. (2014). Atmospheric water and stone weathering, In: Microclimate for cultural heritage. Conservation, restoration, and maintenance of indoor and outdoor monuments, Elsevier, $2^{\text {nd }}$ Ed., pp. 203-243.

DOI: 10.1016/B978-0-444-63296-8.00007-X.

[13] Aperador, W., Vera, R. and Carvajal, A.M. (2012). Industrial byproduct-based concrete subjected to carbonation. Electrochemical behavior of steel reinforcement, Int. J. Electrochem. Sci., 7(12), pp. 12870-12882 . 
[14] Chen, M.-C., Wang, K. and Xie, L. (2013). Deterioration mechanism of cementitious materials under acid rain attack, Eng. Fail. Anal., 27, pp. 272-285. DOI: 10.1016/j.engfailanal.2012.08.007.

[15] Mahadam, P.D. and Mane, A.V. (2013). Effect of simulated acidic rain concentrations on selected materials used in construction, Environ. Sci. Indian J., 8(10), pp. 396-406.

[16] Barbhuiya, S. and Kumala, D. (2017). Behaviour of a sustainable concrete in acidic environment, Sustainability, 9(9), pp. 1-13. DOI: $10.3390 /$ su9091556.

[17] Okochi, H., Kameda, H., Hasegawa, S., Saito, N., Kubota, K. and Igawa, M. (2000). Deterioration of concrete structures by acid deposition-an assessment of the role of rainwater on deterioration by laboratory and field exposure experiments using mortar specimens, Atmos. Environ., 34(18), pp. 2937-2945. DOI: 10.1016/S1352-2310(99)00523-3.

[18] Zhang, Y., Fan, Y. and Li, H. (2012). Influence of simulated acid rain corrosion on the uniaxial tensile mechanical properties of concrete, Int. J. Corros., 2012, 7p. DOI: 10.1155/2012/172394.

[19] Webster, R.P. and Kukacka, L.E., (1986). Effects of acid deposition on Portland cement concrete, In: Materials degradation caused by acid rain, Baboian R., ed., Washington DC, Am. Chem. Soc. Pub., pp. 239-249.

DOI: $10.1021 /$ bk-1986-0318.ch16.

[20] Wang, Y., Niu, D. and Song, Zh. (2017). Effect of acid rain erosion on steel fiber reinforced concrete, J. Wuhan Univ. Technol.-Mater. Sci. Ed., 32(1), pp. 121-128. DOI: 10.1007/s11595-017-1569-y.

[21] Fan, Y.F., Hu, Z.Q., Zhang, Y.Z. and Liu, J.L. (2010). Deterioration of compressive property of concrete under simulated acid rain environment, Constr. Build. Mater., 24(10), pp. 1975-1983. DOI: 10.1016/j.conbuildmat.2010.04.002.

[22] Zhou, C., Zhu, Z., Wang, Z. and Qiu, H. (2018). Deterioration of concrete fracture toughness and elastic modulus under simulated acid-sulfate environment, Constr. Build. Mater., 176, pp. 490-499. DOI: 10.1016/j.conbuildmat.2018.05.049.

[23] Fan, Y.F., Hu, Z.Q. and Luan, H.Y. (2012). Deterioration of tensile behavior of concrete exposed to artificial acid rain environment, Int. Multiscale Mech., 5(1), pp. 41-56. DOI: 10.12989/imm.2012.5.1.041.

[24] Franco-Luján, V.A., Maldonado-García, M.A., Mendoza-Rangel, J.M. and Montes-García, P. (2019). Chloride-induced reinforcing steel corrosion in ternary concretes containing fly ash and untreated sugarcane bagasse ash, Constr. Build. Mater., 198, pp. 608-618. DOI: 10.1016/j.conbuildmat.2018.12.004..

[25] Chousidis, N., Ioannou, I., Rakanta, E., Koutsodontis, C. and Batis, G. (2016). Effect of fly ash chemical composition on the reinforcement corrosion, thermal diffusion and strength of blended cement concretes, Constr. Build. Mater., 126, pp. 86-97. DOI: 10.1016/j.conbuildmat.2016.09.024.

[26] Ahmaruzzaman, M. (2010). A review on the utilization of fly ash, Prog. Energ. Combust., 36(3), pp. $327-363$. DOI: $10.1016 /$ j.pecs.2009.11.003.

[27] ACI Committee 116 (2000). ACI 116R-00: Cement and Concrete Terminology, Farmington Hills Michigan, American Concrete Institute.

[28] Nnadi, E.O., Asce, M. and Lizarazo-Marriaga, J. (2013). Acid corrosion of plain and reinforced concrete sewage systems, J. Mater. Civ. Eng., 25, pp. 1353-1356. DOI: 10.1061/(ASCE)MT.1943-5533.0000641.

[29] Hossain, M.M., Karim, M.R., Hasan, M., Hossain, M.K. and Zain, M.F.M. (2016). Durability of mortar and concrete made up of pozzolans as a partial replacement of cement: A review, Constr. Build. Mater., 116, pp.128-140. DOI: 10. 1016/j.conbuildmat.2016.04.147.

[30] Nie, Q., Zhou, C., Shu, X., He, Q. and Huang, B. (2014). Chemical, mechanical, and durability properties of concrete with local mineral admixtures under sulfate environment in Northwest China, Materials, 7(5), pp. 3772-3785. DOI: $10.3390 / \mathrm{ma} 7053772$.

[31] Takemoto, K. and Uchikawa H. (1980). Hydration of pozzolanic cements, In: Proc. 7th Int. Congress on the Chemistry of Cement, Vol. 1, Sub-Theme IV-2, Paris, pp. 1-21.

[32] Papadakis, V.G. (2000). Effect of supplementary cementing materials on concrete resistance against carbonation and chloride ingress, Cem. Concr. Res., 30(2), pp. 291-299. DOI: 10.1016/S0008-8846(99)00249-5.

[33] Chousidis, N., Rakanta, E., Ioannou, I. and Batis, G. (2015). Mechanical properties and durability performance of reinforced concrete containing fly ash, Constr. Build. Mater., 101(1), pp. 810-817. DOI: 10.1016/j.conbuildmat.2015.10.127.

[34] Tsouli, S., Lekatou, A.G., Kleftakis, S., Matikas, T.E. and Dalla P.T. (2018). Corrosion behavior of 304L stainless steel concrete reinforcement in acid rain using fly ash as corrosion inhibitor, Procedia Struct. Int., 10, pp. 41-48.

DOI: 10. 1016/j.prostr.2018.09.007.

[35] Tsouli, S., Lekatou, A.G. and Kleftakis, S. (2018). The effect of fly ash on the corrosion performance of AISI 316L stainless steel reinforced concrete for application to restoration works of ancient monuments, In: Conservation of Monuments in the Mediterranean Basin, Natural and Anthropogenic Hazards and Sustainable Preservation, Koui M. and Zezza F., eds., Springer Nature Switzerland AG, pp. 171-178. DOI: 10.1007/978-3-319-78093-1. 
[36] Lekatou, A., Sfikas, A.K., Karantzalis, A.E. and Sioulas, D. (2012). Microstructure and corrosion performance of Al32\%Co alloys, Corros. Sci., 63, pp. 193-209. DOI: 10.1016/j.corsci.2012.06.002.

[37] Lekatou, A., Sioulas, D., Karantzalis, A.E. and Grimanelis, D. (2015). A comparative study on the microstructure and surface property evaluation of coatings produced from nanostructured and conventional WC-Co powders HVOFsprayed on Al 7075, Surf. Coat. Tech., 276, pp. 539-556. DOI: 10.1016/j.surfcoat.2015.06.017.

[38] Bertolini, L. and Redaelli, E. (2009). Depassivation of steel reinforcement in case of pitting corrosion: detection techniques for laboratory studies, Mater. Corr., 60(8), pp. 608-616. DOI: 10.1002/maco.200905276.

[39] Ragab, Kh.A., Abdel-Karim, R., Farag, S., El-Ragh, S.M. and Ahmed, H.A. (2010). Influence of $\mathrm{SiC} \mathrm{SiO}_{2}$ and graphite on corrosive wear of bronze composites subjected to acid rain, Tribol. Int., 43(3), pp. 594-601. DOI: 10.1016/j.triboint.2009.09.008.

[40] Matikas, T.E., Karpur, P. and Shamasundar, S. (1997). Measurement of the dynamic elastic moduli of porous titanium aluminide compacts, J. Mater. Sci., 32(4), pp. 1099-1103. DOI: 10.1023/A:1018503127949.

[41] Fujii, K. and Kondo, W. (1974). Kinetics of the hydration of tricalcium silicate, J. Am. Cer. Soc., 57(11), pp. 492-497. DOI: 10.1111/j.1151-2916.1974.tb11400.x.

[42] Cherian, C. and Arnepalli, D.N. (2015). A critical appraisal of the role of clay mineralogy in lime stabilization. Int. J. Geosynth. Ground Eng., 1(8), pp. 1-20, DOI: 10.1007/s40891-015-0009-3.

[43] Pourbaix, M. (1974). Atlas of electrochemical equilibria in aqueous solutions, Houston TX, NACE.

[44] Schweitzer, P.A. (2007). Fundamentals of metallic corrosion, CRC Press.

[45] Bassuoni, M.T. and Nehdi, M.L. (2007). Resistance of self-consolidating concrete to sulfuric acid attack with consecutive pH reduction, Cem. Concr. Res., 37(7), pp. 1070-1084. DOI: 10.1016/j.cemconres.2007.04.014.

[46] Cheewaket, T., Jaturapitakkul, C. and Chalee, W. (2010). Long term performance of chloride binding capacity in fly ash concrete in a marine environment, Constr. B.uild. Mater., 24(8), pp. 1352-1357. DOI: 10.1016/j.conbuildmat.2009. 12.039

[47] Thomas, M. (2007). Optimizing the use of fly ash in concrete. Available at: https://www.cement.org/docs/defaultsource/fc_concrete_technology/is548-optimizing-the-use-of-fly-ash-concrete.pdf. 